\title{
The Impacts of the Strategic Planning Implementation on the Cooperative Members' Participation
}

\author{
Caska \\ Professor of Cooperative Economics, Economic Education Studies Program, \\ Universitas Riau, Pekanbaru, Indonesia \\ Henny Indrawati \\ Lecturer of Development Economics, Economic Education Studies Program, \\ Universitas Riau, Pekanbaru, Indonesia
}

Doi:10.5901/mjss.2017.v8n3p99

\begin{abstract}
This study explores the issue of the impacts of the strategic planning implementation on the cooperative members' participation. Three cooperatives, KUD Kusuma Bakti, KUD Karya Sawit and KUD Mandiri Mojopahit in Kampar Regency, Riau Province, Indonesia were chosen as samples of this study through purposive random sampling based on the elements of: administrators/supervisors, members, community leaders, and government leaders. The results of this study are: (a) Most of the respondents' perceptions on the strategic planning implementation in term of the vision, mission, purpose, creation of business climate, and management information systems were in a good rate, whereas on the members' participation was in a high level; (b) The impact of strategic planning implementation on the Cooperative members' participation was highly significant. These findings show that the cooperative members were encouraged to participate in any cooperative activities through strategic planning implementation.
\end{abstract}

Keywords: strategic planning, members' participation, and cooperative effect.

\section{Introduction}

Members' participation of a cooperative is an important element in the improvement of cooperatives. It is a requirement for the improvement of cooperative performances, preventing from corruption, and the cooperative manager is the one who is in charge of this responsibility (Caska, 2014). On the other side, members' participation is the central issue in the development of cooperatives. Members as well as the owners and the customers should perform their functions. If these functions are not implemented, the cooperative is not improving. Thus, the participation of members in the cooperatives requires strategic and operational planning on an ongoing basis (Zareshki \& at. al., 2015).

Cooperative development should pay attention to the participation of members. Cooperative members will participate if the cooperatives benefit them as a customer as well as the owner. Participation of members is determined by the extent to which the cooperative can provide benefits that isn't obtained from its competitorsn(Röpke, 2008; Sadriev \& Pratchenko, 2014). The feasibility study of the cooperative must be based on the ability of cooperatives to create special benefits for members. Cooperatives which can not produce specific benefits do not meet the feasibility standard to be implemented. For cooperative members, the benefits of the cooperative must be greater than its competitors' (Röpke, 2008; Henny Indrawati \& Caska, 2015).

The phenomenon of the cooperative based on observational data show: (1) The functions of cooperatives are not as high as desired by members; (2) The cooperative organizational structure, from the perspective of members, is deemed too complicated, and so difficult to understand for decision making process and controll; (3) The purpose of the cooperative, from the viewpoint of members, is often considered too narrow; (4) The cooperative manager is very responsive to the direction of the board of committee, but not responsive to the direction of members; (5) Benefits of cooperative is also open for non- members so there is no different benefits for members and non-members (Caska, 2016). 
Specific research discusses the relationship between the implementation of strategic planning and the participation of members has not been done. Efforts to increase the participation of members through the implementation of strategic planning model has been done in a cooperative in Kampar regency. The main business units of the cooperative is trading palm oil. This study identified perception of cooperative members in formulating the strategic planning model (Caska, 2014).

In addition, the studies linked the principle of voluntary cooperation and open membership as well as the owners and customers. The nature of voluntary and open membership allowed the heterogeneous composition of membership. The higher the degree of heterogeneity in membership the lower the level of members' compactness in achieving the cooperative objectives (Röpke, 2008; Caska, 2015).

The principle of dual identity in cooperative is an excellent point for the cooperatives in improving members participation. As the owners, members must contribute ideas for the progress of cooperatives, and contribute equity capital for cooperatives' businesses. While as customers, members must participate in the business of cooperatives. If the principle of dual identity can be optimized, the implementation of strategic planning of cooperatives would increase the participation of members (Röpke, 2008; Caska, 2014).

This study addresses the issue of how far the implementation of strategic planning, done by the board, can increase the participation of members. Further, this study also explores issues of what kind of strategic planning implementation model used in order to increase members participation. Analyzing all the key issues as the central theme in this study is considered very relevant in the development of cooperatives.

\section{Research Problem}

The research problem is formulated as following: (a) how is the implementation of cooperative strategic planning and participation of members of the cooperative? and (b) how is the impact of the implementation of strategic planning on the participation of members of the cooperative?

\section{Research Objectives}

The objectives of this study are: (a) to analyse the implementation of cooperative strategic planning and participation of cooperative members; and (b) to analyse of the impact of the implementation of strategic planning on the participation of members of the cooperative.

\section{Literature Review}

The key tasks of the cooperative is to carry out the service of goods and services that support the economic enhancement of household members. If the cooperative services satisfy the members, participation of members in the form of contributory participation and incentives will also increase (Caska, 2015). Participation of the members of the cooperative can be improved if cooperative services are in accordance with the interests and needs of members. There are three types of suitability models of participation of members of the cooperative: 1) a compatibility between the cooperative management decisions with the interests of the members; 2) a compatibility between the cooperative management capabilities with the requirements/interests of program tasks; and 3) a compatibility between the output programs whit the needs of the members (Yan, L. \& Yan, J., 2013; Caska, 2014).

In addition, the role of cooperative communications services is essential in enhancing the participation of members of the cooperatives. The elements in the cooperatives communication program consists of: community, consumers and customers, employees and staffs, supervisors, universities, financial institutions and industries, distributors, other cooperatives, government, prospective members, as well as members. The elements are very useful for administrators I supervisors as a feedback in providing services to members (Röpke, 2008; Caska, 2015).

In communicating the work program to the members cooperative management needs to implement an effective strategic planning. This is important because an effective strategic planning can determine the performance of the board in the long term in serving members of the cooperative (Azriyah Amir \& at. al., 2016). If strategic planning can be implemented through operational planning every year, the cooperative vision for the welfare of the members can be achieved (Caska, 2016).

On the other hand, the welfare of members can be seen from the impact of the cooperatives, which is an additional satisfaction felt by members as a result of their participation in cooperatives. The impact of cooperatives is not only a total satisfaction obtained during one period (several years), but it is the result of a comparison between the level of satisfaction obtained after participating. Measuring the impact of cooperatives is equal to measuring the level of satisfaction of the members (enterprises or households) at least within one period of visible embodiment of revenues (Röpke, 2008). 
The cooperatives effect can usually be seen from the aspects of: (1) market position towards better price. When members' bargaining position increases the marketing channels are shortener; (2) increased capacity of adjustment to the market as a result of the experience of managers in the business, more skillful negotiation skills and business practices / trade better; (3) Increasing investment because of joint venture; (4) The use of better facilities so that the cost per unit decreases; (5) The occurrence of a better specialization; (6) The occurrence of the transfer of risk from the company to the members of the cooperative; and (7) The occurrence of a positive influence on members by improving the quality of production and others (Skokan \& at. al., 2013; Caska, 2016).

The cooperative effect can be created only if the cooperative can do efficiency in business. Economies of scale is impotent in a company as it can lower the cost per unit resulting from increased levels of output. This cost decrease is obtained from internal economies of scale and the external economies of scale. Scale internal economic efforts occur within a company or a factory. The expansion of output resulted in a decrease in average fixed costs and average variable cost. While the scale of the external economic effort as the impact of a merger or amalgamation in which its business units become more economical (Caska, 2016).

Scale economic enterprises in the company will bring impact on the achievement of minimum efficient size. This happens because of real economies and pecuniary economies. The business scale of the real economy is economies of scale achieved as a result of a decrease in the incremental production costs. Real economies can be performed in: a) activity of the production process; b) sale or marketing activity; c) managerial activities; and d) transport and storage activities. While pecuniary economies is the result of the improvement of bargaining position so that it can receive a rebate for goods bought, lower interest rates, cheaper advertising costs, and cheaper transport costs (Hemert \& et. al., 2013; Melnik \& Dyrdonova, 2015).

Some policies to restructure cooperatives in the heading of cost efficiency are by: (1) encouraging a single purpose cooperative with an eligible core business; (2) encouraging merger / amalgamation for small cooperatives; (3) determining the criteria for membership as owners and customers and the contractual relationship between the members and the cooperative; (4) making sure that members are willing to supply additional capital when needed; (6) conducting focused education and training to increase the efficiency of business members, the administrator skills, management skills, and skills of employees; (7) establishing strategic alliance with local and foreign cooperative; (8) utilizing government policies, legal protection, credit, taxation, business reserve, research, and education / training; and (9) applying of the principle of parsimony by the rules of the cooperatives (Yuyun, 2002; Caska, 2014; Saunila \& Ukko, 2014; Sonia, 2016).

Low cost strategies in cooperatives need to be applied as a basic strategy to generate a competitive advantage for members. The low-cost strategy can be done if the cooperative is able to work efficiently (Porter, 1995). Efficiency can occur if the cooperative has a strategic plan that is used as a guide in the operational activities every year. If the implementation of cooperative strategic planning can be done in programs and activities each year, the members' participation rate will increase as a result of obtaining the benefits of the cooperative (Anderson \& Eshima, 2013).

\section{Methodology}

\subsection{Reseach Location and Time}

This research is a study on three cooperatives, namely: KUD Kusuma Bakti, KUD Karya Sawit dan KUD Mandiri Mojopahit Kampar regency in Riau Province Indonesia from May to October 2016. The three cooperatives were chosen by the following considerations: 1) The main business of the cooperatives is oil palm products; 2) the business of cooperatives is relatively stable and evolving over the past 10 years; 3 ) they are unique cooperatives, although their business area in the countryside but the business units are similar to business units in urban areas, such as grocery stores mini market, and rental conference hall.

\subsection{Research Type and Sample}

The samples were taken by purposive random sampling by taking into account elements of: a) 20 persons of management and supervisory board of; b) 100 persons of cooperative members; c) 20 persons of public leaders; and 4) 10 persons of government leaders.

\subsection{Data Analysis Technique}

The data is processed and analyzed by using descriptive analysis. Quantitative data is processed by using SPSS version 21 , while the qualitative data is processed and interpreted in accordance with the constructivist approach. 


\section{Findings and Discussion}

\subsection{Perception on Implementation of Strategic Planning}

The description of strategic planning implementation done by cooperatives can be seen in the following table:

Table 1. Perceptions of Respondents to Vision of Cooperatives

\begin{tabular}{llcc}
\hline & Options & Freq. & $(\%)$ \\
\hline 1. & Cooperative's vision can be understood and disseminated easily & 68 & 45.33 \\
2. & Cooperative's vision is difficult to understand, but socialized & 62 & 41.33 \\
3. & Cooperative's vision is difficult to understand not socialized & 20 & 13.34 \\
\hline Total & 150 & 100 \\
\hline
\end{tabular}

\section{Source: own processing}

Table 1 shows that most respondents consider that a cooperative vision is easily understood and disseminated. These conditions still need to be socialized because there are some who believed that the vision of cooperative is difficult to understand. Understanding the vision for cooperative members is very important because vision is a series of sentences that express idealogy or cooperative dreams to be achieved in the future. Moreover, in the vision of the cooperative there are also the values, aspirations and needs of the cooperative in the future (Caska, 2016). Vision is a statement about the purpose of the cooperative expressed in the products including services offered, needs to be addressed, the people who are served, the values obtained as well as the aspirations and ideals of the future. The vision statement should be described well in order to be a theme that could unite all the units in the cooperatives, and as a source of creativity and cooperative innovation. In order to be easily understood by members of the cooperative, before deciding vision it should be conducted internal and external environmental scrutiny so that the vision formulated is in accordance with the aspirations of members of the cooperative (Parnell, 2013).

Table 2. Perceptions of Respondents on Conformity of Mission with Cooperative's Vision

\begin{tabular}{|c|c|}
\hline Options & Freq. $(\%)$ \\
\hline 1. The mission of the cooperative is in accordance with the vision of a cooperative, easy to understand, and socialized & $70 \quad 46.67$ \\
\hline 2. The mission of the cooperative is in accordance with the vision of a cooperative, difficult to understand and socialized & 36.67 \\
\hline 3. The mission of the cooperative is not in accordance with the vision of a cooperative, difficult to understand and socialized & 16.66 \\
\hline Total & 100 \\
\hline
\end{tabular}

Source: own processing

Table 2 shows that most respondents consider that cooperative missions are in accordance with the vision of cooperatives, easy to understand, and socialized. Although missions of cooperative are socialized, but there are respondents who are difficult to understand the mission of the cooperatives. This indicates that respondents need to understand that the missions of the cooperatives so that the cooperatives are able to produce qualified products and services that meet the needs, desires and expectations of their customers (Šebestová \& Nowáková, 2013). To ensure that the mission announced is a good mission, the missions of the cooperative must: (a) be broad enough to be applied over several years from the time specified; (b) be specific enough to communicate directions; (c) focus on the competence or the ability of the cooperative; and (d) be free of jargon and words that are not meaningful (Sok \& O'Cass, 2011).

Table 3. Perception of Respondents on Conformity of Goal with Cooperative's Vision

\begin{tabular}{|c|c|}
\hline Options & Freq. $(\%)$ \\
\hline 1. The goals of the cooperatives are in accordance with cooperatives' missions, easily understood, and socialized & $77 \quad 51.33$ \\
\hline 2. The goals of the cooperatives are in accordance with the cooperatives' missions, easy to understand but not socialized & 4932.67 \\
\hline 3. The goals of the cooperatives are not in accordance with the cooperatives' missions, difficult to understand but socialized & 2416.00 \\
\hline Total & 100 \\
\hline
\end{tabular}

Source: own processing 
Table 3 shows that most respondents consider that cooperatives' objectives are in accordance with cooperatives' missions, easily understood, and socialized. Although the purpose of cooperatives have been socialized but there are respondents who think that the goal of cooperative is still difficult to understand. This condition needs an attention from administrators / supervisors in order to make the goals of the cooperative better understood by members of the cooperatives. In order to understand the goals of cooperative for members, formulating the objectives of the cooperative must consider all the forces involved in cooperative activities (Bryson, 2004). Formulation of objectives is the result of deliberation and agreement to satisfy all parties. Therefore, the cooperative board of committee needs to discuss the objectives of cooperative in annual members' meeting as the highest forum of a cooperative.

Administrators/supervisors in formulating cooperative objectives need to pay attention to: (a) The process of formulation of objectives should include individuals who are responsible for the achievement of objectives; (b) The manager (as formulators of general purpose) should be responsible for lowering the goals at lower levels; (c) Objectives should be realistic, aligned with the internal and external environment; (d) The goals must be clear, reasonable, and challenging for members of the cooperative; (e) The general objective should be stated simply to be more easily understood and remembered by the executor; ( $f$ ) The purpose of functional areas must be consistent with the general purpose; (g) Management should always revisit its intended purpose (Parnell, 2013).

Table 4. Perceptions of Respondents on Creation of Atmosphere, Climate and Conducive Business Environment

\begin{tabular}{|c|c|}
\hline Options & Freq. $(\%)$ \\
\hline 1. Cooperative owns and carry out more than one activity that can create a conducive atmosphere, climate, and business environment & 10670.67 \\
\hline 2. The cooperative does not have activities that can create a conducive atmosphere, climate, and business environment & $44 \quad 29.33$ \\
\hline Total & 150 \\
\hline
\end{tabular}

\section{Source: own processing}

Table 4 shows that most respondents consider cooperatives had more than one activity that have been implemented to create a conducive atmosphere, climate, and business environment. This condition needs to get the attention of administrators and supervisors that cooperatives can provide good services to their members. Thus, the cooperatives can give satisfaction to the members and members will actively participate in the various activities of the cooperatives (Caska, 2016). Then, to create a conducive atmosphere, climate and business environment in the cooperative, it is important to formulate a comprehensive manner in the strategic planning of cooperatives (Sadriev \& Pratchenko, 2014; MartinezConesa \& et. al., 2016). It is intended that the cooperative can maintain harmonization between members in encouraging members to participate and for incentives contribution.

Table 5. Perceptions of Respondents on Management Information System to Support Cooperative Administration

\begin{tabular}{|c|c|c|}
\hline Options & Freq. & $(\%)$ \\
\hline 1. The management information system to support the cooperative administration is good enough & 66 & 44.00 \\
\hline 2. The management information system to support the administration of the cooperative is unfavorable & 59 & 39.33 \\
\hline 3. The management information system to support the administration of the cooperative is not good enough & 25 & 16.67 \\
\hline Total & 150 & 100 \\
\hline
\end{tabular}

\section{Source: own processing}

Table 5 shows that $44 \%$ of respondents consider the management information system to support the administration of the cooperative is good. The rest (56\%) express unfavorable and they think that there is no good management information systems in support of the administration of the cooperatives. This condition needs to be paid attention by management and supervisor of cooperatives. In the competition of the highly competitive global business, the role of management information systems is very important in winning business competition (Zeng \& et. al., 2010; Song \& et. Al., 2011; AbdelMaksoud \& et. al., 2015). In addition, the cooperative management information system can increase confidence of members that a cooperative can provide welfare of its members. This is important because if the trust of members can be enhanced the participation of any members may also increase (Caska, 2016).

Respondents' perceptions of the implementation of strategic planning with indicators of the perception of the vision, mission, purpose, creation of business climate, and information management systems turned out to be average at a good rate. This is somewhat understandable because the sample cooperatives in this research are relatively stable and 
evolving over the last 10 years. In addition, samples from cooperative members are members who have a rational characteristics. It can be seen from the cooperative business unit although in the countryside but the unit activities are equal to modern trade unit, credit unit, health services unit, and rental of meeting and sports building unit.

\subsection{Perception on Member Participation}

The description of members participation can be seen from two types of participation, they are the incentives participation and contributive participation. Incentives participation is a participation in exploiting the potential range of services provided by the cooperatives to support the interests of the members. Contributive participation is a participation in contributing ideas for the progress of cooperatives to equity capital in the business, and participate to oversee the organizations and their business.

Table 6. Perception of Respondents on Cooperative Participation

\begin{tabular}{clcc}
\hline & Options & Freq. & $(\%)$ \\
\hline 1. & Low & 25 & 16.67 \\
2. & Medium & 79 & 52.67 \\
3. & High & 46 & 30.66 \\
\hline & Total & 150 & 100 \\
\hline
\end{tabular}

Source: own processing

Table 6 shows that most respondents consider the participation of cooperatives is in the medium and high levels. This condition can be categorized as a good participation because the category of the general development of cooperatives in Indonesia is in low participation (Caska, 2015). Good participation of members is very conducive to realize the goals of cooperatives and the welfare of their members (Zareshki \& et. al., 2015). This is because the cooperative is a unique organization that is commonly called as "dual identity". Members are both as the owner and as customer of the cooperative, so that the participation of cooperative members is very important in realizing the objectives of cooperatives. In the non-cooperative company, customer service is a top priority in maintaining customers satisfaction. Consumers and owners of the cooperative are at same parties which are also members of the cooperative. Therefore, an excellent service in the cooperative is very essential to be done (Caska, 2011).

\subsection{Impacts of Strategic Planning Implementation on Cooperatives Members Participation}

The impacts of the implementation of strategic planning on cooperative members' participation are shown in Table 7 and Table 8.

Tablel 7. Anova Relationship of Implementation of Strategic Planning with Cooperative Members' Participation

\begin{tabular}{lccccc}
\hline Model & Sum of Squares & Df & Mean Square & F & Sig. \\
\hline Regression & 1824.683 & 1 & 1824.683 & 129.215 & $.000^{\mathrm{a}}$ \\
1 Residual & 2089.957 & 148 & 14.121 & & \\
$\quad$ Total & 3914.640 & 149 & & & \\
\hline
\end{tabular}

a. Predictors: (Constant), Strategic Planning of Cooperative Members' Participation

b. Dependent Variable: participation of cooperative members

Testing of research model that links the implementation of cooperatives' strategic planning as independent variable and the participation of cooperative members as dependent variable shows that the value of $r$ (correlation coefficient) of 0.683 and $R^{2}$ (coefficient of determination) of 0.466 . Testing with the $F$-test reveals that $F$ counting $=129,215$ is higher than $F$ table, namely F $0.05(1)(150)=3.07$, which means that the null hypothesis $(\mathrm{Ho})$ is rejected. Thus, the variable of members participation can be explained by the implementation of strategic planning.

The test results of the model indicate that the participation of members of cooperatives (46.6\%) can be explained by the implementation of cooperatives strategic planning. While the rest $(53.4 \%)$ are explained by other factors. In this study, other factors outside the model is quite big, $53.4 \%$. This is understandable due to only one independent variable included in the model. 
Table 8. Coefficient Relationship of Strategic Planning Cooperation with Member Participation

\begin{tabular}{lccccc}
\hline \multirow{2}{*}{ Model } & \multicolumn{2}{c}{ Unstandardized Coefficients } & Standardized Coefficients & \multirow{2}{*}{ T } & \multirow{2}{*}{ Sig. } \\
\cline { 2 - 4 } & $\mathrm{B}$ & Std. Error & Beta & & \\
\hline \multirow{2}{*}{ (Constant) } & 5.130 & 2.269 & & .261 & .025 \\
PSK & .449 & .040 & .683 & 11.367 & .000 \\
\hline
\end{tabular}

a. Dependent Variable: participation of cooperative members

Results of regression test show that:

The regression equation:

$\mathrm{Y}=5.130+0.449 \mathrm{X}$

T-hit. $=(2.261)(11.367)$

Sig. $=(0.025)(0.000)$

Note:

$Y=$ Participation of cooperative members

$X=$ Implementation of strategic planning

The regression equation can be interpreted as follows:results of testing by t-test, t-count $=(11.367)$ lies beyond the critical point, $t(0.05)(150)=1.660$, which means the null hypothesis $(\mathrm{Ho})$ is rejected. Thus, the implementation of strategic planning has a positive impact on the participation of cooperative members. The impact of the implementation of strategic planning on the participation of members is 0.449 . This means that if the implementation of strategic planning is enhanced by one unit, it will increase the participation of members by 0.449 units, assuming by ceteris paaribus. These findings could be taken into consideration that the increasing participation of cooperative members requires strategic planning within a period of five years and annual operational planning.

Based on statistics, the implementation of cooperative strategic planning is considered important in the effort to increase the participation of cooperative members. Nowadays, the implementation of cooperative organizations pays less attention to the implementation of strategic planning, so the cooperatives development is difficult to predict. The cooperatives grow rapidly and be recognized, but then the cooperatives face many problems and even facing bankruptcy (Yuyun, 2002). In the future, the development of cooperatives is not enough only by applying the operational planning conducted through the Annual Members Meeting, but also by implementing strategic planning which has a five-year period. Through the strategic planning, performance of management, supervisors, and cooperativecan be measured and assessed by the achievements of its performance (Ates \& et. al., 2013; Caska, 2016).

The impacts of the implementation of strategic planning on the participation of cooperative members can be analyzed through two effects, namely the impact on the incentives participation and contributives participation. First, the impact of the implementation of strategic planning on participation incentives. Participation in the position of members as customers is required to participate in exploiting the potential range of services provided by the cooperative business unit to support the interests of the members. The position of members as customers is reflected by the large volume of transactions conducted by the members of the cooperative business unit. The theory of cooperative uncertainty may explain the relationship between the volume of transactions with costs decrease. When all the intermediary are completely informed there will be no transaction costs (Röpke, 2008; Blackburn \& et. al., 2013). Thus, if all members of the cooperative have a commitment as a customer, the transaction costs of the cooperative does not need to exist. In addition to the reduction in transaction costs, the position of members as customers will also bring benefits to the low costs of the organization and the information which in turn will lower the cost of transformation (Yuyun, 2002).

Second, contributive participation is affected by the implementation of strategic planning. The results are understandable given based on the results of previous studies, direct influence of services to business success and the indirect influence of service to business success through the participation of members. The results of this study are line with previous theories stating that the implementation of strategic planning, the cooperative members are required to participate in his capacity as owner, the members contribute to the formation and growth of cooperatives in the form of financial contributions in the form of equity, savings, compulsory savings and voluntary savings. (Caska, 2014; Baumgartner, 2016).

\section{Conclusions}

The average respondents' perceptions on the implementation of strategic planning with indicators of perception about the vision, mission, purpose, creation of business climate, and management information systems is at a good rate. The 
average perception of respondents on participation of the members is at a high level.

The impact of the implementation of strategic planning on the participation of members is 0.449 . If the implementation of the strategic planning enhanced by one unit, it will increase the participation of members by 0.449 unit, assuming by ceteris paribus. The increase of members' participation to cooperative is required each year by annual operational and strategic planning within a period of five years.

\section{Acknowledgments}

The author would like to thank the Rector of Universitas Riau through the Chairman of LPPM Universitas Riau that has provided research funds through BOPTN Research Grant Scheme 2016.

\section{References}

Abdel-Maksoud, A., S. Elbanna, H. Mahama, \& R. Pollanen. (2015). The Use of Performance Information in Strategic Decision Making in Public Organizations. International Journal of Public Sector Management 28 (7): 528-549. DOI:10.1108/JJPSM-06-2015-0114.

Anderson, B. S., \& Y. Eshima. (2013). The Influence of Firm Age and Intangible Resources on the Relationship between Entrepreneurial Orientation and Firm Growth among Japanese SMEs. Journal of Business Venturing, 28(3), 413-429.

Ates, A., Garengo, P., Cocca, P \& Bititci, U. (2013). The development of SME managerial practice for effective performance management. Journal of Small Business and Enterprise Development, 2(1):28-54.

Azriyah Amir, Sofiah Md Auzair \& Rozita Amiruddin. (2016). Cost managemen, entrepreneurship and competitiveness of strategic priorities for small and medium enterprises. Procedia-Social and Behavior Sciences, 219, 84-90.

Baumgartner, R.J., Rauter, R., (2016). Strategic perspectives of corporate sustainability management to develop a sustainable organization. Journal of Cleaner Production, 140, 81-92.

Blackburn, R.A., Hart, M., \& Wainwright, T. (2013). Smaall business performance: Business, Strategy, and Owner-manager characteristics. Journal of Small Business and Enterprise Development, 20 (1), 8-27.

Bryson, J.M. (2004). Strategic Planning for Public and Nonprofit Organizations. United States of America: Published by Jossey Bass.

Caska. (2011). Determinan dan Strategi Penumbuhan Klaster Bisnis Koperasi. Trikonomika: Jurnal Ekonomi. 10(2) 105-115. . (2014). Dinamika Pembangunan Ekonomi dan Koperasi. Pekanbaru-Indonesia: UR Press.

. (2015). Upaya Peningkatan Keunggulan Bersaing Dalam Masyarakat Ekonomi ASEAN (MEA) Melalui Pengembangan Model Perencanaan Strategis Koperasi Berbasis Komoditas Kelapa Sawit. Pekanbaru-Indonesia: LPPM Universitas Riau. .(2016). Revitalisasi Model Kelembagaan dan Pembiayaan Koperasi Dalam Upaya Peningkatan Keunggulan Bersaing Dalam Masyarakat Ekonomi ASEAN. Pekanbaru-Indonesia: LPPM Universitas Riau.

Hemert, P., Nijkamp, P. \& Masurel, E. (2013). From innovation to commercialization through networks and agglomerations: analysis of sources of innovation, innovation capabilities and performance of Dutch SMEs. Annals of Regional Science, 50(2), 425-452.

Henny Indrawati \& Caska (2015). Financing Models for sago cake makers in supporting the acceleration of family economic improvement. Mediterranean Journal of Social Sciences, 6(6) 310-318.

Martinez-Conesa I, Soto-Acosta P, \& Manzano MP. (2016). Corporate social responsibility and its effect on innovation and firm performance: An empirical research in SMEs. Journal of Cleaner Production. DOI: 10.1016/j.jclepro.2016.11.038.

Melnik, A.N \& Dyrdonova, A.N. (2015). Application of operational analysis for evaluasion of the impact of different factors on performance efficiency on the enterprises forming the regional industrial cluster. Mediterranean Journal of Social Sciences, 6(6) 144-146.

Parnell, J. A. (2013). Uncertainty, Generic Strategy, Strategic Clarity, and Performance of Retail SMEs in Peru, Argentina, and the United State. Journal of Small Business Management, 51(2) 215-234.

Porter, M.E. (1985). Competitive Advantage: Creating and Sustaining Superior Performance. New York: Fee Press.

Röpke, Jochen.(2008). The Economic Theory of Cooperative. Marburg-Germany:

Sadriev, A.R. \& Pratchenko, O.V. (2014). Idea management in the system of innovative management. Mediterranean Journal of Social Sciences, $5(12)$ 155-158.

Saunila, M. and Ukko, J. (2014). Intangible aspects of Innovation capabilities in SMEs: impacts of size and industry. Journal of Engineering Technological Management, 33(1), 32-46.

Šebestová, J., \& Nowáková, K. (2013). Dynamic Strategy for Sustainable Business Development: Mania or Hazard ? The Amfiteatru Economic Journal, 15(34), 442-454.

Skokan Karel, \& at. al. (2013). Strategic Planning and Business Performance of Micro, Small and Medium-Sized Enterprises. Journal of Competitiveness. 5(4) 57-72.

Sok, P. \& O'Cass, A. (2011). Achieving superior innovation-based performance outcomes in SMEs through innovation resourcecapability complementarity", Industrial Marketing Management, 40(8), 1285-1293.

Song, M., Im, S., Bij, H., \& Song, L. Z. (2011). Does Strategic Planning Enhance or Impede Innovation and Firm Performance. Journal of Product Inovation Management, 28(4), 503-520.

Sonia Taneja Mildred Golden Pryor Mario Hayek. (2016). Leaping innovation barriers to small business longevity. Journal of Business Strategy, 37(3), $44-51$. 
Yan, L. \& Yan, J. (2013). Leadership, organizational citizenship behavior, and innovation in small business: an empirical study. Journal of Small Business and Entrepreneurship, 26 (2), 183-199.

Yuyun Wirasasmita. (2002). Penemuan Kembali dan Revitalisasi Kaidah-Kaidah Koperasi dalam Usaha Mencapai Keunggulan Kompetitif. Bandung-Indonesia: UNPAD.

Zareshki, M. R. \& et. al. (2015). Studying effective factors on employees empowerment of headquarters of islamshahr municipality. Mediterranean Journal of Social Sciences, 6(6) 144-146.

Zeng, S.X., Xie, X.M. \& Tam, C.M. (2010). Relationship between cooperation networks and innovation performance. Technovation, 30 (3), 181-194. 